\title{
FRONTIER: DRAINAGE WATER RECYCLING IN THE HUMID REGIONS OF THE U.S.: CHALLENGES AND OPPORTUNITIES
}

\author{
Christopher H. Hay, ${ }^{1,}$, Benjamin D. Reinhart², Jane R. Frankenberger², \\ Matthew J. Helmers ${ }^{3}$, Xinhua Jia ${ }^{4}$, Kelly A. Nelson ${ }^{5}$, Mohamed A. Youssef ${ }^{6}$ \\ ${ }^{1}$ Iowa Soybean Association, Ankeny, Iowa, USA. \\ ${ }^{2}$ Department of Agricultural and Biological Engineering, Purdue University, West Lafayette, Indiana, USA. \\ ${ }^{3}$ Iowa Nutrient Research Center, Department of Agricultural and Biosystems Engineering, Iowa State University, Ames, Iowa, USA. \\ ${ }^{4}$ Department of Agricultural and Biosystems Engineering, North Dakota State University, Fargo, North Dakota, USA. \\ ${ }_{6}^{5}$ Division of Plant Sciences, University of Missouri, Novelty, Missouri, USA. \\ ${ }^{6}$ Department of Biological and Agricultural Engineering, North Carolina State University, Raleigh, North Carolina, USA. \\ * Correspondence: chay@iasoybeans.com.
}

\section{HighLights}

- Drainage water recycling captures and stores agricultural drainage water for reuse as supplemental irrigation.

- Drainage water recycling can both increase crop production and benefit downstream water quality.

- Depending on management, drainage water recycling can also provide other complementary benefits.

- Research needs to advance drainage water recycling are presented and discussed.

Keywords. Drainage water quality, Drainage water reuse, Subsurface drainage, Supplemental irrigation, Agricultural resiliency.

$\mathrm{F}$ armers in the humid regions of the eastern U.S. face water management challenges from increasing frequency and duration of too wet and too dry periods, often occurring within the same year. Artificial drainage, in the form of subsurface (tile) drains or open ditches, has long been used to remove excess water in poorly drained soils of the region. However, artificial drainage is a major pathway for losses of nitrogen and phosphorus from farm fields to nutrient-sensitive water bodies such as the Chesapeake Bay, Great Lakes, and Gulf of Mexico. Irrigation is not historically common in the eastern U.S., but the irrigated area in the 31 eastern states increased by $36 \%$ between 1997 and 2017 (USDA-NASS, 2014, 2019) as a risk management strategy for recurring periods of short-term and long-term drought (Vories and Evett, 2010). These water management challenges (wetter springs and drier summers) and water quality impacts are expected to worsen under future climate projections for the region (USGCRP, 2018).

Drainage water recycling (DWR) is an emerging practice in which subsurface and surface drainage water is captured and stored for reuse as supplemental irrigation during dry

\footnotetext{
cC)(1) $\Theta$ The authors have paid for open access for this article. This (c) ${ }_{\mathrm{BY}}$ NC ND work is licensed under a Creative Commons AttributionNonCommercial-NoDerivatives 4.0 International License https://creative commons.org/licenses/by-nc-nd/4.0/

Submitted for review on 13 July 2020 as manuscript number NRES 14207; approved for publication as an Invited Frontier Article by the Natural Resources \& Environmental Systems Community of ASABE on 24 February 2021.
}

periods (Frankenberger et al., 2017). Controlled drainage, or drainage water management, and subirrigation have been studied and promoted for many years for their ability to increase yields and reduce nutrient loss (Skaggs, 1999). These systems are commonly limited to relatively flat fields that also meet other specific conditions (Fouss et al., 1999). Furthermore, controlled drainage only manages the drainage outlet, so in dry years, there may be no drainage water to conserve, which limits its potential to positively impact yields (Skaggs et al., 2012). Subirrigation adds the ability to put water back into the system, but it requires a separate water supply suitable in both quantity and quality. DWR is adaptable to many more situations and offers the potential for more complementary benefits. It is one of three practices, along with controlled drainage, studied for increasing storage for greater resiliency in the drained landscape as part of the Transforming Drainage project (Reinhart et al., 2016; https://transformingdrainage.org). Similar systems for capturing irrigation tailwater and surface runoff are increasingly being constructed in the Mid-South region of the U.S. (Czarnecki et al., 2017; Yaeger et al., 2018). However, the capture of subsurface drainage water as a primary source of supplemental water supply distinguishes DWR from irrigation tailwater recovery and other farm reservoirs. The USDANRCS Conservation Practice Standard for irrigation tailwater recovery was revised in 2020 and renamed "irrigation and drainage tailwater recovery" to recognize the new scope of subsurface drainage water recovery (USDA-NRCS, 2020).

There are many potential configurations for DWR systems (e.g., reservoir design, irrigation systems, pumping systems) 
to accommodate different site conditions (fig. 1). DWR can capture subsurface drainage water from and reapply it to the same field, or offsite drainage water can be captured for irrigation at another location. DWR can also be implemented at multiple scales, from individual field or farm scales to part of a larger drainage infrastructure in which multiple farms contribute or draw water from a shared reservoir. This practice has great potential to increase resiliency to both excess and deficit water conditions. By capturing and reusing drainage water and nutrients that otherwise would have been discharged downstream, DWR can reduce nutrient loading from drained cropland. Depending on design and management, DWR also has potential to provide additional benefits for recreation, wildlife, and if implemented at a large enough scale, address downstream water quantity concerns.

Baker et al. (2012) provided a rationale for supplemental irrigation to increase crop productivity, mitigate climate risk, support advanced cropping systems, and provide other ancillary benefits, including water quality. A limited number of field research studies of DWR have established the promise of the practice for improved crop production and water quality. One of the more comprehensive studies in the eastern U.S. was conducted at three sites in Ohio (Allred et al., 2014), and data collected from these sites and data from new sites as part of, or related to, the Transforming Drainage project (Reinhart et al., 2016) are being used to further evaluate the practice. However, there are a number of remaining questions that need to be answered to support increased adoption of the practice. We have grouped these questions into five broad categories: (1) hydrology of DWR systems, (2) crop yield benefits, (3) water quality benefits, (4) complementary benefits, and (5) implementation and management considerations. For each category, we reviewed the existing literature related to DWR to determine what is known and then identified research needs to advance DWR. This article provides recommendations for future research that would expand our knowledge of DWR and support greater implementation of the practice. We also provide suggestions for conducting DWR research to ensure that the necessary data are collected to best answer the open questions. Increased knowledge of the multiple aspects of DWR will enhance our ability to promote the practice for enhanced cropping system resilience and improved water quality.

\section{HYDROLOGY OF DWR SYSTEMS}

Understanding the hydrology of DWR systems and the interactions among weather, soil, crop, drainage and irrigation system design, and management factors can help address the unanswered questions. DWR systems are different from other irrigated systems in that they involve the irrigation of naturally poorly drained soils with frequent shallow water tables (fig. 2). In these soils, determination of the irrigation water requirement is not as simple as the difference between evapotranspiration (ET) and effective precipitation because the shallow water table interacts with the unsaturated zone, which alters the crop root depth and contributes to crop ET (Fan et al., 2017). Although there are alternatives to solving the soil water balance for irrigation management, understanding the soil water balance is still needed for research and design purposes. The captured drainage water in a DWR system, on its own, may not always be enough to meet the full irrigation demand. Although deficit irrigation strategies have been studied, management of supplemental irrigation in humid regions on poorly drained soils where precipitation is the primary water source creates different challenges than in areas where irrigation is the primary water source.

In soils that require artificial drainage for crop production, the dynamics of soil water in the root zone include both downward movement of infiltrated water (precipitation and irrigation) driven by gravitational forces and upward movement from the water table driven by capillary rise. The latter, frequently referred to in the drainage literature as upward flux, can be a major contributor to crop ET and varies depending on water table depth, soil type, and crop species and growth stage (Kolars et al., 2019; Niaghi and Jia, 2019). Upward flux is particularly challenging to measure and is often estimated using hydrologic models, but it is still unknown for different soils, crops, and water table depths.

Understanding the reservoir water balance is also key for the design and management of DWR systems. Research on on-farm irrigation reservoirs for capturing surface drainage and irrigation tailwater for irrigation in the Mid-South (Yaeger et al., 2018) can inform that understanding. However, subsurface drainage hydrology is different from that of surface runoff. Models will be needed to simulate the hydrology

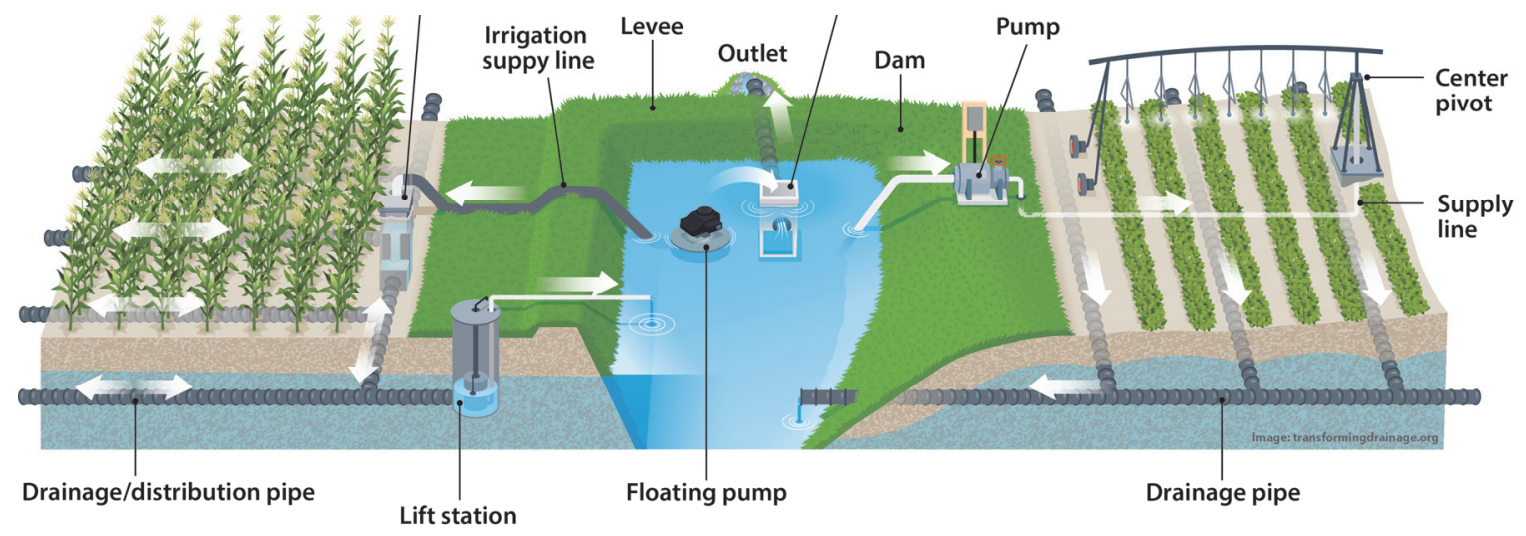

Figure 1. Various potential drainage water recycling (DWR) configurations. Irrigation methods include subirrigation (left) and sprinkler irrigation (right), while the reservoir may be excavated with the spoil used as a levee to increase storage (left) or as an embankment dam (right). 


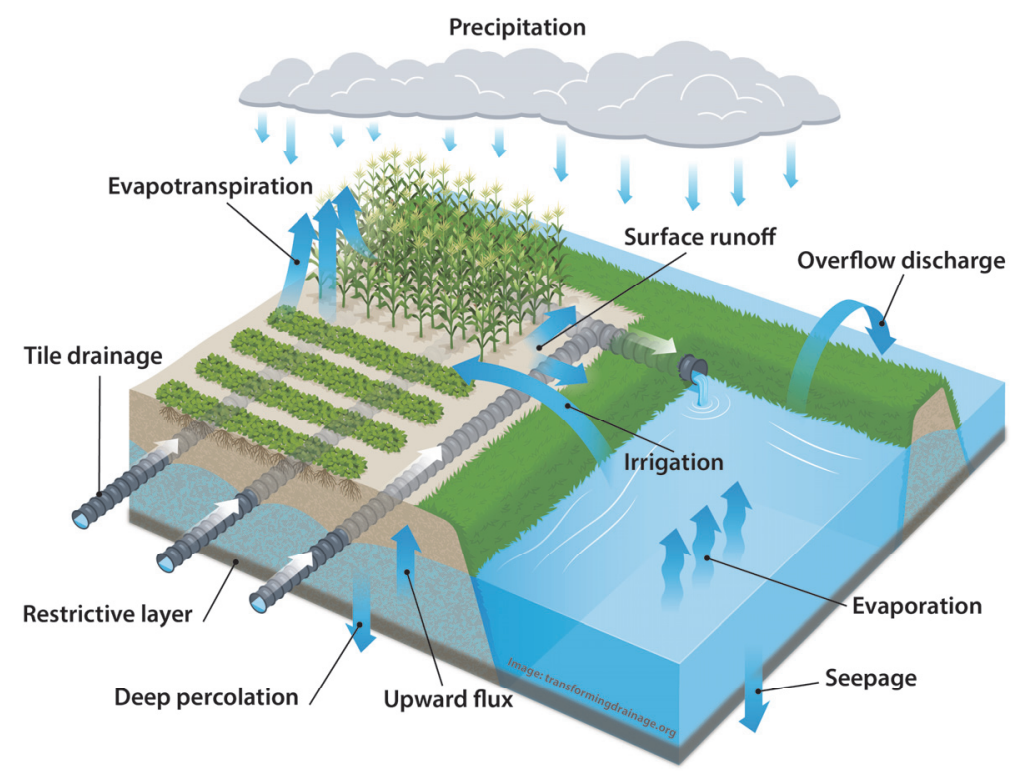

Figure 2. Hydrologic flowpaths of a DWR system, including several that need to be better quantified. In particular, upward flux from the shallow water table may be an important contributor to crop ET in naturally poorly drained soils, and irrigation from the reservoir needs to take into account precipitation uncertainty.

of DWR using long-term climatological records to predict drainage amounts and irrigation needs as affected by spatial and temporal variations in precipitation.

DWR systems are also expected to affect and be affected by watershed hydrology. Understanding the interaction between the hydrologic processes occurring at both the field and watershed scales is critical for the design and management of DWR systems to maximize performance and minimize or avoid tradeoffs. Inflow from upstream contributing areas could be a key water balance component of DWR reservoirs. Inflow from upstream drainage areas depends on geographic location, precipitation and watershed characteristics, and hydrologic connectivity of the DWR reservoir to the larger watershed. Research is needed to investigate the effects of these factors on the amount of water that can be potentially harnessed and reused for supplemental irrigation within a specific hydrogeophysical setting.

DWR reservoirs intercept surface and subsurface runoff, potentially modulating the hydrographs of storm events and intercepting nutrients and sediment before they reach downstream surface waters. However, these reservoirs could negatively influence stream flow under low-flow conditions, which could be harmful to aquatic ecosystems, especially for small headwater watersheds. The effect of DWR on stream flow has not been investigated, and research is needed on how the capture and recycling of drain flow affects stream flow and hydrologic response during wet and dry periods.

Well-coordinated field-scale experiments and computer simulation modeling at both the field and landscape scales will be needed to advance our understanding of DWR systems. For field experiments, measuring soil physical properties in the soil profile, identifying the restrictive soil layer, and monitoring water table depth and soil water conditions in the root zone are needed, along with measured drainage, surface runoff, and irrigation amounts. Data generated by field experiments will enable the improvement and testing of models and tools that can be used to simulate different hydrological and biogeochemical processes and their interactions that affect the DWR system. These models and tools can be used for design, performance evaluation, and development of management strategies for DWR systems.

\section{CROP YiELd BENEFITS}

Crop yield benefit is one of the most important goals for a DWR system. Rainfed yields are commonly $50 \%$ or less of yield potential, whereas irrigated yields approach $80 \%$ of yield potential (Lobell et al., 2009). Supplemental irrigation from DWR can help reduce yield reductions from water limitations and improve yield stability (Willison et al., 2021). While there is extensive knowledge of irrigation management in arid and semi-arid regions (Hoffman et al., 2007; Lascano and Sojka, 2007), managing irrigation on poorly drained soils in humid regions remains a challenge because of precipitation uncertainty and upward flux from shallow water tables.

\section{MEASURED AND Modeled CROP Yield INCREASES}

Supplemental irrigation using a DWR system has increased grain yields by up to $61 \%$ and $31 \%$ for corn and soybean, respectively, compared to free drainage (fig. 3), but the available data are based on a limited number of studies at sites having unique water management systems, soils, and production characteristics (table 1).

Modeling research such as Reinhart et al. (2019) has also demonstrated the crop yield benefits of DWR systems. Benefits are expected to increase as climate change leads to greater crop stress due to both drought and waterlogging/flooding. In Ohio, corn yield benefits of DWR were predicted to increase from $21 \%$ under current climate 


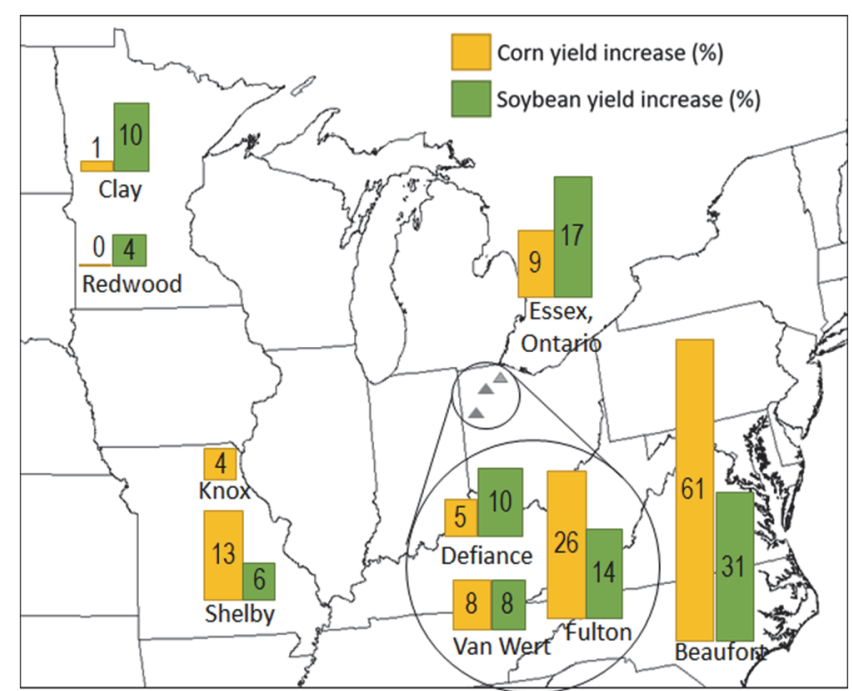

Figure 3. Corn and soybean yield increase (\%) of drainage water recycling systems compared to free or controlled (clay) drainage for counties in the eastern U.S. and Canada (studies described in table 1).

conditions to $30 \%$ under future climate projections, while soybean increases were predicted to rise from $12 \%$ to $20 \%$ (Baule et al., 2017). Determining the magnitude of benefits, including economic analyses, across the region under current and future climate conditions requires additional research.

\section{RESEARCH NEEDED TO EXPAND CROP RESPONSES TO DWR}

Further research is needed on irrigation management on poorly drained soils. Most current research on crop response to DWR has used subirrigation (table 1). However, landscapes with soils not suitable for subirrigation due to slopes greater than $1 \%$ or low-permeability soil layers above subsurface drains require other irrigation methods, such as sprinkler or drip irrigation. For subirrigation, research is needed on how technology (sensors and automation) can be used to enhance high-yield production systems and minimize risk of excess water stress. Management should target critical stages of crop development to increase yield stability and enhance the productivity of water use. Research is also needed to quantify the value of nutrients recycled in the irrigation water and potential risks of pesticides, salts, or other toxicants.

There may also be opportunities for producers to modify their crop management strategies to optimize DWR performance and take advantage of higher commodity prices that often coincide with widespread droughts and floods.
A DWR system also allows diversified cropping systems (Baker et al., 2012; Niaghi, 2019; Tan et al., 2007), but little research exists that evaluates the feasibility of alternative cropping systems or integrated crop and livestock management systems using DWR within the corn and soybean dominated landscape of the humid U.S. Hydrologic and cropping system modeling of DWR is needed to provide economic optimization of the systems by evaluating sizing, cropping system, and water quality interactions, which would allow implementation of decision support tools.

\section{WATER QUALITY BENEFITS}

The reservoir used in DWR not only provides water storage for supplemental irrigation, it also reduces site discharge, which reduces downstream pollutant loading. Studies from Canada documented nitrogen loss reductions of $40 \%$ to $70 \%$ (Drury et al., 1996, 2009) and phosphorus loss reductions of $12 \%$ to $36 \%$ (Tan and Zhang, 2011; Tan et al., 2007) from DWR. Modeling work by Reinhart et al. (2019) predicted substantial reductions in downstream nitrogen (24\% to $37 \%$ ) and phosphorus (21\% to $39 \%$ ) delivery in Iowa and Indiana. The overall load reduction is dependent on how much water is retained and reused in the field.

In addition to pollutants reduced through discharge reduction, concentration reductions have been found simply due to storage (Dong et al., 2009; Karki et al., 2018; Shao et al., 2013). Concentration reductions in the reservoir are likely due to denitrification for nitrogen (Crumpton et al., 2020) and deposition for phosphorus (Schmadel et al., 2019), although limited research has directly measured these in DWR systems. Understanding these processes and their interactions is key for determining the nutrient assimilative potential of the reservoir, the water residence time required for specific processes, and the conditions under which the reservoir could become a source of nutrients (particularly P) to downstream waters.

As DWR systems are implemented, there is a need for monitoring across a range of sites and climatic conditions to document downstream load reductions and evaluate any water quality tradeoffs. This work should evaluate concentrations of pollutants in the inflow and outflow water as well as the levels in the stored water, since this stored water indicates the quality of the water used for irrigation. An example of a potential tradeoff is that while total phosphorus loads leaving the reservoir will be lower than loads from a conventional free drainage system because of the portion recycled onto the field, there is a potential for particulate phosphorus

Table 1. Irrigation water delivery, storage, and soils provide unique opportunities for DWR to impact crop production in the eastern U.S.

\begin{tabular}{ccc}
\hline Study Sites & Site Characteristics \\
\hline $\begin{array}{c}\text { Clay and Redwood } \\
\text { (Minnesota, U.S.) }\end{array}$ & $\begin{array}{c}\text { Surface drip irrigation was used at Redwood in southern Minnesota, } \\
\text { and a drainage ditch served as the water source for subirrigating crops } \\
\text { including sugarbeet at Clay in western Minnesota. }\end{array}$ \\
\hline $\begin{array}{c}\text { Defiance, Fulton, Van Wert } \\
\text { (Ohio, U.S.) }\end{array}$ & $\begin{array}{c}\text { Wetland reservoir subirrigation systems treated and recycled water to irrigate } \\
\text { crops. Higher yields were observed in clay loam soils than clay soils. }\end{array}$ \\
$\begin{array}{c}\text { Essex } \\
\text { (Ontario, Canada) }\end{array}$ & $\begin{array}{c}\text { Wetland reservoir recycled surface and subsurface water from test fields } \\
\text { in contrasting growing seasons. }\end{array}$ \\
\hline $\begin{array}{c}\text { Knox and Shelby } \\
\text { (Missouri, U.S.) }\end{array}$ & $\begin{array}{c}\text { Drought-prone claypan soil had greater response to DWR compared to a } \\
\text { floodplain soil when surface and subsurface drainage water was captured. }\end{array}$ \\
\hline $\begin{array}{c}\text { Beaufort } \\
\text { North Carolina, U.S.) }\end{array}$ & $\begin{array}{c}\text { In a single year of research, crops were highly responsive, but adequate } \\
\text { water storage was a concern. }\end{array}$ \\
\hline
\end{tabular}


to be released from sediment as dissolved phosphorus, and as a result, higher concentrations at low-flow periods (Shao et al., 2013). Research should also examine how denitrification might be impacted by the bank and bottom soils of the reservoir and reservoir configuration. Elevated nutrient levels in the reservoir may create the potential for harmful algae growth in the reservoir, which could impact use of the water or downstream waterbodies from reservoir releases, and this should be examined in future research. Additional tradeoffs that should be evaluated are the potential buildup of salt, pesticide, and bacteria levels in the reservoir and released to downstream waters.

\section{COMPLEMENTARY BENEFITS \\ DoWnSTREAM FLOW MANAGEMENT BENEFITS}

Water storage in the landscape has been used for decades as an effective method to provide rural flood control. While most of this storage targeted the capture of surface runoff, the strategic use and location of water storage in tile-drained landscapes can also play an important role in flood control strategies (Hey and Philippi, 1994). At a more local scale, the capture and storage of artificial drain flow can provide benefits to existing drainage infrastructure, such as providing additional drainage capacity in locations where aging infrastructure may be undersized or inadequate due to more recent increases in drainage extent and intensity (Brandel et al., 2016; Kanwar et al., 1983).

Research is needed to develop strategies for managing the tradeoffs between flood and peak flow and irrigation goals. Modeling approaches can evaluate potential benefits and tradeoffs based on varying landscape scale, flood frequency and magnitude, underlying hydrology, and drainage intensity. Research should also consider any potential impacts from DWR on environmental flows supporting downstream ecosystems and uses.

\section{WILDLIFE BENEFITS}

DWR reservoirs may also provide wildlife and ecological benefits, and these benefits can be increased through intentional design and management for species of special interest or concern. A wetland-reservoir DWR system documented the presence of multiple fish, amphibian, and reptile species occurring within the separate wetland and reservoir habitats (Smiley and Allred, 2011). Further research on quantifying the role of DWR in supporting wildlife is needed at both the field and landscape scale. At the field scale, research should evaluate potential water quality impacts (e.g., elevated levels of nutrients and pesticides) and different reservoir sizes, configurations, and water level management strategies to determine differences in wildlife use and survival. Spatial analyses at the landscape scale could determine the impact of reservoir distribution and habitat connectivity on wildlife populations, particularly for species of notable conservation concern. Strategies that support improved wildlife benefits should also be evaluated against producer and landowner goals (e.g., providing irrigation water supply, reducing nutrient loss).

\section{Other Potential Benefits InCluding \\ ENERGY ProduCTION}

Floating solar photovoltaic energy production ("floatovoltaics") is starting to be implemented in artificial water bodies around the world (Ranjbaran et al., 2019; Spencer et al., 2019) and could potentially provide energy and income to help increase the adoption of DWR. Reservoirs may also provide an additional water source for on-farm uses (e.g., livestock, wash water, etc.) or for the production of bioenergy crops (Berry et al., 2017), or if located at elevated locations in the landscape, could provide energy storage by pumping water uphill when surplus energy is available. Economic and market analyses are needed to determine the potential value of such systems to agricultural producers and energy companies, and research is needed to better describe the site characteristics that support these energy production systems.

\section{IMPLEMENTATION AND MANAGEMENT CHALLENGES TO IMPLEMENTATION}

Despite the crop yield, water quality, downstream flow management, wildlife, and other benefits that DWR can provide, there are many challenges for implementation. Reservoirs that are large enough to provide substantial storage are expensive. Tailwater recovery systems in the Mississippi Delta with field areas ranging from 58 to 182 ha documented by Omer et al. (2019) cost from $\$ 400,000$ to $\$ 900,000$, and a recent DWR system in the Midwest irrigating 42 ha cost \$400,000 (T. van Wagner, personal communication, 27 Oct. 2020). In addition to construction costs, the value of the land taken out of production must be considered. There is also considerable uncertainty in the economic benefits of DWR. Research-based irrigation management strategies for poorly drained soils are needed, especially for farmers who are very familiar with drainage but lack experience with irrigation. Strategies are needed for defining sites where costs would be lowest and economic benefits greatest.

\section{IDENTIFYING SUITABLE SITES FOR DWR}

Suitable sites are those that benefit from both improved drainage and supplemental irrigation. In the humid U.S., there has been much research on agricultural drainage benefits. However, there is a need to collect and interpret relevant existing studies and identify future research needs to evaluate crop response to various amounts of supplemental irrigation on naturally poorly drained soils. Results from this research would help inform more site-specific estimates of how much water can be captured, stored, and used as supplemental irrigation along with the economic benefits. In cases where there is not sufficient water to capture and store, complementary water sources (e.g., groundwater well, nearby surface water) may also be used but would add costs to the practice and may reduce water quality benefits. The quality of both the additional water source and the captured water must also be sufficient to avoid yield reductions.

Other siting and cost reduction considerations may include retrofitting existing structures such as borrow pits for construction, stormwater retention ponds, or reservoirs 
constructed for flood control and irrigation (Hanson et al., 2007). Less profitable or inconvenient portions of the farm, such as unirrigated center pivot corners or depressional areas, may also provide locations to construct reservoirs. Geospatial siting tools considering climate, soils, topography, and land use can be coupled with crop models for economic assessment and feasibility of specific locations.

\section{Management Strategies to MaXimize BENEFITS AND AVOID NEGATIVE IMPACTS}

The development of management strategies will be necessary for decision-making and to optimize DWR benefits. For optimizing crop yield benefits, irrigation strategies should be developed to make best use of reservoir water supplies by targeting irrigation at critical crop growth periods. For water quality and peak flow reduction, reservoir water levels may be reduced at certain periods of the year to create storage capacity prior to anticipated peak flows, or to capture water flows when nutrient losses from the field are high. For wildlife benefits, reservoir hydrology may be manipulated to provide suitable conditions for key wildlife species, and vegetative communities can be established to provide habitat and improve water quality. Drainage systems may also be managed, for example, to reroute drainage away from the reservoir to avoid contamination during times when flows of undesirable pollutants (e.g., pesticides, salts) are high. There are a variety of other practices that may complement or enhance DWR in the field (e.g., cover crops, enhanced nutrient and pest management, alternative crop rotations) and at the edge of field (e.g., bioreactors, saturated buffers, phosphorus filters).

Research on these strategies should be guided by results and inferences that will come from the research needs described in prior sections and take into consideration related work in topic areas such as deficit irrigation, water reuse, and salinity management in traditionally irrigated areas of the U.S., controlled drainage systems, water level management strategies for flood control reservoir systems, and wetland management strategies.

\section{CONCLUSIONS}

Drainage water recycling is a promising practice for improving the productivity and climate resiliency of crop production in subsurface-drained areas of the eastern U.S. By capturing subsurface drainage water that would otherwise have gone downstream and recycling it back into the field, DWR can also improve water quality by reducing nutrient and other pollutant loads from subsurface drainage systems. Increased water storage has potential to provide a number of other benefits, depending on management, including flood peak reduction, wildlife benefits, an additional water source for other uses, and energy production.

Despite the many potential benefits, a number of remaining research questions need to be answered before DWR can be promoted for widespread adoption. Better understanding is needed of the hydrology of DWR and how to design and manage DWR systems to maximize benefits and minimize any unintended consequences. The many components and aspects of DWR intersect with many of the specialty areas within agricultural and biological engineering, so the research will need to engage engineers and scientists beyond drainage engineers. In addition to the engineering and physical science questions discussed here, economic and other social science questions need to be addressed to advance DWR, requiring a multidisciplinary approach. DWR has potential to transform crop production on drained lands, which are some of the most productive in the world, to create cropping systems that are more resilient to climate risks, strengthen the water-food-energy nexus, and promote longterm sustainability. Progress on the research needs identified here will move us closer to that goal.

\section{ACKNOWLEDGEMENTS}

This material is based on work that is supported by the USDA National Institute of Food and Agriculture under Award No. 2015-68007-23193 and was partially funded by the soybean checkoff through the Iowa Soybean Association.

\section{REFERENCES}

Allred, B. J., Gamble, D. L., Clevenger, W. B., LaBarge, G. A., Prill, G. L., Czartoski, B. J., ... Brown, L. C. (2014). Crop yield summary for three wetland reservoir subirrigation systems in northwest Ohio. Appl. Eng. Agric., 30(6), 889-903. https://doi.org/10.13031/aea.30.10501

Baker, J. M., Griffis, T. J., \& Ochsner, T. E. (2012). Coupling landscape water storage and supplemental irrigation to increase productivity and improve environmental stewardship in the U.S. Midwest. Water Resour. Res., 48(5). https://doi.org/10.1029/2011WR011780

Baule, W., Allred, B., Frankenberger, J., Gamble, D., Andresen, J., Gunn, K. M., \& Brown, L. (2017). Northwest Ohio crop yield benefits of water capture and subirrigation based on future climate change projections. Agric. Water Mgmt., 189, 87-97. https://doi.org/10.1016/j.agwat.2017.04.019

Berry, P., Yassin, F., Grosshans, R., \& Lindenschmidt, K.-E. (2017). Surface water retention systems for cattail production as a biofuel. J. Environ. Manag., 203, 500-509. https://doi.org/10.1016/j.jenvman.2017.08.019

Brandel, C. (2016). Conservation drainage: Innovative strategies that provide win-win solutions. Proc. 10th Intl. Drain. Symp. ASABE Paper No. 162493335. St. Joseph, MI: ASABE.

Crumpton, W. G., Stenback, G. A., Fisher, S. W., Stenback, J. Z., \& Green, D. I. (2020). Water quality performance of wetlands receiving nonpoint-source nitrogen loads: Nitrate and total nitrogen removal efficiency and controlling factors. J. Environ. Qual., 49(3), 735-744. https://doi.org/10.1002/jeq2.20061

Czarnecki, J. M. P., Omer, A. R., \& Dyer, J. L. (2017). Quantifying capture and use of tailwater recovery systems. J. Irrig. Drain. Eng., 143(1), 05016010. https://doi.org/10.1061/(ASCE)IR.1943-4774.0001124

Dong, B., Mao, Z., Brown, L., Chen, X., Peng, L., \& Wang, J. (2009). Irrigation ponds: Possibility and potentials for the treatment of drainage water from paddy fields in Zhanghe Irrigation System. Sci. China Ser. E: Tech. Sci., 52(11), 3320. https://doi.org/10.1007/s11431-009-0364-1

Drury, C. F., Tan, C. S., Gaynor, J. D., Oloya, T. O., \& Welacky, T. W. (1996). Influence of controlled drainage-subirrigation on surface and tile drainage nitrate loss. J. Environ. Qual., 25(2), 317-324.

https://doi.org/10.2134/jeq1996.00472425002500020016x 
Drury, C. F., Tan, C. S., Reynolds, W. D., Welacky, T. W., Oloya, T. O., \& Gaynor, J. D. (2009). Managing tile drainage, subirrigation, and nitrogen fertilization to enhance crop yields and reduce nitrate loss. J. Environ. Qual., 38(3), 1193-1204. https://doi.org/10.2134/jeq2008.0036

Fan, Y., Miguez-Macho, G., Jobbágy, E. G., Jackson, R. B., \& Otero-Casal, C. (2017). Hydrologic regulation of plant rooting depth. Proc. Natl. Acad. Sci., 114(40), 10572-10577. https://doi.org/10.1073/pnas.1712381114

Fouss, J. L., Evans, R. O., \& Belcher, H. W. (1999). Design of controlled drainage and subirrigation facilities for water table management. In R. W. Skaggs \& J. van Schilfgaarde (Eds.), Agricultural drainage (pp. 719-742). Madison, WI: ASA, CSSA, SSSA. https://doi.org/10.2134/agronmonogr38.c21

Frankenberger, J., Reinhart, B., Nelson, K., Bowling, L., Hay, C., Youssef, M., \& Allred, B. (2017). Questions and answers about drainage water recycling for the Midwest. ABE-156. West Lafayette, IN: Purdue University Extension.

Hanson, G. J., Caldwell, L., Lobrecht, M., McCook, D., Hunt, S. L., $\&$ Temple, D. (2007). A look at the engineering challenges of the USDA small watershed program. Trans. ASABE, 50(5), 1677-1682. https://doi.org/10.13031/2013.23959

Hey, D. L., \& Philippi, N. S. (1994). Reinventing a flood-control strategy. In G. E. Freeman \& A. G. Frazier (Eds.), Proceedings of the scientific assessment and strategy team workshop on hydrology, ecology, and hydraulics (pp. 47-52). Washington, DC: U.S. Government Printing Office.

Hoffman, G. J., Evans, R. G., Jensen, M. E., Martin, D. L., \& Elliott, R. L. (Eds.). (2007). Design and operation of farm irrigation systems. St. Joseph, MI: ASABE.

Kanwar, R. S., Johnson, H. P., Schult, D., Fenton, T. E., \& Hickman, R. D. (1983). Drainage needs and returns in northcentral Iowa. Trans. ASAE, 26(2), 457-464. https://doi.org/10.13031/2013.33958

Karki, R., Tagert, M. L., \& Paz, J. O. (2018). Evaluating the nutrient reduction and water supply benefits of an on-farm water storage (OFWS) system in east Mississippi. Agric. Ecosyst. Environ., 265, 476-487. https://doi.org/10.1016/j.agee.2018.06.024

Kolars, K., Jia, X., Steele, D. D., \& Scherer, T. F. (2019). A soil water balance model for subsurface water management. Appl. Eng. Agric., 35(4), 633-646. https://doi.org/10.13031/aea.13038

Lascano, R. J., \& Sojka, R. E. (Eds.). (2007). Irrigation of agricultural crops. Madison, WI: ASA, CSSA, SSSA. https://doi.org/10.2134/agronmonogr30.2ed

Lobell, D. B., Cassman, K. G., \& Field, C. B. (2009). Crop yield gaps: Their importance, magnitudes, and causes. Ann. Rev. Environ. Resour., 34(1), 179-204. https://doi.org/10.1146/annurev.environ.041008.093740

Nelson, K. A. (2017). Soybean yield variability of drainage and subirrigation systems in a claypan soil. Appl. Eng. Agric., 33(6), 801-809. https://doi.org/10.13031/aea.12276

Nelson, K., Harder, D., \& Mungyeko-Mayola, M. (2017). Corn response to drainage water recycling in a blackoar silt loam. In Greenley Memorial Research Center field day report (pp. 150151). Novelty, MO: University of Missouri.

Niaghi, A. R. (2019). Advanced evapotranspiration measurement for crop water management in the Red River valley. $\mathrm{PhD}$ diss. Fargo, ND: North Dakota State University, Department of Agricultural and Biosystems Engineering.

Niaghi, A. R., \& Jia, X. (2019). New approach to improve the soil water balance method for evapotranspiration estimation. Water, 11(12), article 2478. https://doi.org/10.3390/w11122478

Niaghi, A. R., Jia, X., Steele, D. D., \& Scherer, T. F. (2019). Drainage water management effects on energy flux partitioning, evapotranspiration, and crop coefficients of corn. Agric. Water
Mgmt., 225, article 105760. https://doi.org/10.1016/j.agwat.2019.105760

Omer, A. R., Henderson, J. E., Falconer, L., Kröger, R., \& Allen, P. J. (2019). Economic costs of using tailwater recovery systems for maintaining water quality and irrigation. J. Environ. Mgmt., 235, 186-193. https://doi.org/10.1016/j.jenvman.2019.01.038

Ranjbaran, P., Yousefi, H., Gharehpetian, G. B., \& Astaraei, F. R. (2019). A review on floating photovoltaic (FPV) power generation units. Renew. Sustain. Energy Rev., 110, 332-347. https://doi.org/10.1016/j.rser.2019.05.015

Reinhart, B. D., Frankenberger, J. R., Abendroth, L., Ahiablame, L., Bowling, L., Brown, L., ... Youssef, M. (2016). Drainage water storage for improved resiliency and environmental performance of agricultural landscapes. Proc. 10th Intl. Drainage Symp. Conf. (pp. 1-8). ASABE Paper No. 162557416. St. Joseph, MI: ASABE. https://doi.org/10.13031/IDS.20162557416

Reinhart, B. D., Frankenberger, J. R., Hay, C. H., \& Helmers, M. J. (2019). Simulated water quality and irrigation benefits from drainage water recycling at two tile-drained sites in the U.S. Midwest. Agric. Water Mgmt., 223, article 105699.

https://doi.org/10.1016/j.agwat.2019.105699

Schmadel, N. M., Harvey, J. W., Schwarz, G. E., Alexander, R. B., Gomez-Velez, J. D., Scott, D., \& Ator, S. W. (2019). Small ponds in headwater catchments are a dominant influence on regional nutrient and sediment budgets. Geophys. Res. Lett., 46(16), 9669-9677. https://doi.org/10.1029/2019GL083937

Shao, D., Tan, X., Liu, H., Yang, H., Xiao, C., \& Yang, F. (2013). Performance analysis of on-farm irrigation tanks on agricultural drainage water reuse and treatment. Resour. Cons. Recycl., 75, 1-13. https://doi.org/10.1016/j.resconrec.2013.03.011

Singh, G., \& Nelson, K. A. (2021). Long-term drainage, subirrigation, and tile spacing effects on maize production. Field Crops Res., 262, article 108032. https://doi.org/10.1016/j.fcr.2020.108032

Skaggs, R. W. (1999). Water table management: Subirrigation and controlled drainage. In R. W. Skaggs \& J. van Schilfgaarde (Eds.), Agricultural drainage (pp. 695-718). Madison, WI: ASA, CSSA, SSSA.

Skaggs, R. W., Fausey, N. R., \& Evans, R. O. (2012). Drainage water management. J. Soil Water Cons., 67(6), 167A-172A. https://doi.org/10.2489/jswc.67.6.167A

Smiley Jr., P. C., \& Allred, B. J. (2011). Differences in aquatic communities between wetlands created by an agricultural water recycling system. Wetlands Ecol. Mgmt., 19(6), 495-505. https://doi.org/10.1007/s11273-011-9231-5

Spencer, R. S., Macknick, J., Aznar, A., Warren, A., \& Reese, M. O. (2019). Floating photovoltaic systems: Assessing the technical potential of photovoltaic systems on man-made water bodies in the continental United States. Environ. Sci. Tech., 53(3), 1680-1689. https://doi.org/10.1021/acs.est.8b04735

Tan, C. S., \& Zhang T., Q. (2011). Surface runoff and sub-surface drainage phosphorus losses under regular free drainage and controlled drainage with sub-irrigation systems in southern Ontario. Canadian J. Soil Sci., 91(3), 349-359. https://doi.org/10.4141/cjss09086

Tan, C. S., Zhang, T. Q., Drury, C. F., Reynolds, W. D., Oloya, T., \& Gaynor, J. D. (2007). Water quality and crop production improvement using a wetland-reservoir and draining/subsurface irrigation system. Canadian Water Resour. J., 32(2), 129-136. https://doi.org/10.4296/cwrj3202129

USDA-NASS. (2014). 2012 census of agriculture: Farm and ranch irrigation survey (2013) (AC-12-SS-1). Washington, DC: USDA National Agricultural Statistics Service. Retrieved from https://www.nass.usda.gov/Publications/AgCensus/2012/Online _Resources/Farm_and_Ranch_Irrigation_Survey/ 
USDA-NASS. (2019). 2017 census of agriculture: 2018 irrigation and water management survey (AC-17-SS-1). Washington, DC: USDA National Agricultural Statistics Service. Retrieved from https://www.nass.usda.gov/Publications/AgCensus/2017/Online Resources/Farm_and_Ranch_Irrigation_Survey/index.php

USDA-NRCS. (2020). National handbook of conservation practices 450-NHCP notice 170. Washington, DC: USDA Natural Resources Conservation Service. Retrieved from https://directives.sc.egov.usda.gov/OpenNonWebContent.aspx?c ontent $=45518$.wba

USGCRP. (2018). Impacts, risks, and adaptation in the United States. In D. R. Reidmiller, C. W. Avery, D. R. Easterling, K. E. Kunkel, K. L. Lewis, T. K. Maycock, \& B. C. Stewart (Eds.), Fourth national climate assessment (Vol. II). Washington, DC: U.S. Global Change Research Program. https://doi.org/10.7930/NCA4.2018

Varga, T., \& Strock, J. S. (2018). Opportunities and challenges for supplemental irrigation in southwest Minnesota. Winter Crops and Soils Day. Lamberton, MI: University of Minnesota Southwest Research and Outreach Center.

Vories, E. D., \& Evett, S. R. (2010). Irrigation research needs in the USA mid-south and southeast, humid and sub-humid regions. Proc. 5th National Decennial Irrigation Conf. ASABE Paper No. IRR108679. St. Joseph, MI: ASABE. https://doi.org/10.13031/2013.35852

Willison, R. S., Nelson, K. A., Abendroth, L. J., Chighladze, G., Hay, C. H., Jia, X., ... Wikle, C. K. (2021). Corn yield response to subsurface drainage water recycling in the Midwestern United States. Agron. J., 113, 1865-1881. https://doi.org/10.1002/agj2.20579

Yaeger, M. A., Massey, J. H., Reba, M. L., \& Adviento-Borbe, M. A. (2018). Trends in the construction of on-farm irrigation reservoirs in response to aquifer decline in eastern Arkansas: Implications for conjunctive water resource management. Agric. Water Mgmt., 208, 373-383.

https://doi.org/10.1016/j.agwat.2018.06.040 